(typically patients with Axis I disorders). The challenge for psychiatrists and other professions will be to ensure that patients with chronic illness receive adequate (community) mental healthcare in the future.

\section{Reference}

Metz, J.\& Poorter, J. (1998) The Netherlands. In Medicine and Medical Education in Europe (ed. G. Eysenbach). Thieme.

\title{
The teaching and training of psychiatry in Thailand
}

\author{
Pichet Udomratn, MD FRCPsychT
}

Department of Psychiatry, Faculty of Medicine, Prince of Songkla University, Hat Yai, Songkhla 90110, Thailand, email upichet@medicine.psu.ac.th

\begin{abstract}
$\mathrm{n}$ Thailand, we have only two programmes for residency training in psychiatry: one is general or adult psychiatry, which takes 3 years to complete; the other is child and adolescent psychiatry, which takes 4 years. There are nine institutes that offer residency training but only three medical schools have the capacity to offer training in both general and child psychiatry (Table 1).

The curriculum for training in adult psychiatry is similar to that in many other Asian countries. It is outlined in Table 2. Most residents learn psychiatry in both in- and out-patient settings simultaneously, although some institutes prefer to have their trainees initially learn in a psychiatric ward, during their first 3-6 months of training.

It is compulsory that all accredited training institutes arrange at least 2 hours of supervision per week. Trainees will meet one or two supervisors during the 3-month rotation. Most of them will have one supervisor who is in charge of the ward staff and another who supervises care of out-patients. The second- and third-year residents will have an extra supervisor specifically to supervise psychotherapy cases.
\end{abstract}

\section{Outline of the curriculum}

Most institutes emphasise interviewing techniques and mental status examination during the first 3 months. The techniques are taught through lectures and observation. Thereafter they are practised throughout the programme, both individually with feedback by supervisors and in group sessions - 'interviewing seminars' - with feedback from peers and staff.

Trainees learn the concepts of psychological treatment largely from lectures, but also in book clubs and topic discussion sessions.

They have to manage at least two psychotherapy cases during the 3 years of training, including one of short-term therapy and another of long-term treatment. They normally review cases with their supervisor once a week and bring cases for discussion in a psychotherapy seminar once a month. Apart from psychotherapy, trainees must also study another psychological treatment method, such as behaviour therapy, cognitive therapy or family therapy. They are not required to practise these methods, however, as there are too few skilled and certified therapists in those areas to supervise them.

For electroconvulsive therapy (ECT), trainees will listen to a lecture first. Then they will observe staff and/or senior

Table 1 Institutes that provide psychiatric residency training in Thailand

\begin{tabular}{|c|c|c|c|}
\hline Medical school/institute & Province & $\begin{array}{l}\text { General } \\
\text { psychiatry }\end{array}$ & $\begin{array}{l}\text { Child } \\
\text { psychiatry }\end{array}$ \\
\hline Siriraj Medical School & Bangkok & Yes & Yes \\
\hline Ramathibodi Medical School & Bangkok & Yes & Yes \\
\hline Phramongkutklao Hospital & Bangkok & Yes & No \\
\hline $\begin{array}{l}\text { Chulalongkorn Medical } \\
\text { School }\end{array}$ & Bangkok & Yes & Yes \\
\hline Chiang Mai Medical School & Chiang Mai & Yes & No \\
\hline $\begin{array}{l}\text { Prince of Songkla Medical } \\
\text { School }\end{array}$ & Songkhla & Yes & No \\
\hline Khon Kaen Medical School & Khon Kaen & Yes & No \\
\hline $\begin{array}{l}\text { Somdet Choapraya Institute } \\
\text { of Psychiatry }\end{array}$ & Bangkok & Yes & No \\
\hline $\begin{array}{l}\text { Yuwaprasart } \\
\text { Waithayopathum } \\
\text { Psychiatric Hospital }\end{array}$ & Samut Prakan & No & Yes \\
\hline
\end{tabular}

Table 2 General psychiatry curriculum in Thailand

\begin{tabular}{|lll} 
Year of training & Topic & Duration \\
First year & $\begin{array}{l}\text { General adult psychiatry } \\
\text { Mental health hospital psychiatry }\end{array}$ & 6 months \\
& Neurology & 3 months \\
Second year & $\begin{array}{l}\text { General adult psychiatry } \\
\text { Child and adolescent psychiatry }\end{array}$ & 6 months \\
& Consultation-liaison psychiatry & 3 months \\
Third year & $\begin{array}{l}\text { General adult psychiatry } \\
\text { Addiction psychiatry }\end{array}$ & 6 months \\
& $\begin{array}{l}\text { Community psychiatry } \\
\text { Forensic psychiatry }\end{array}$ & 1 months \\
& $\begin{array}{l}\text { Day hospital, juvenile court } \\
\text { Electives }\end{array}$ & 0.5 months \\
& & 3 months
\end{tabular}


residents performing ECT and will eventually practise ECT by themselves.

In terms of management skills, they must take the role of chief resident at least for some period in the last year of training. They will also be involved in ongoing qualityimprovement activities which are related to the hospital accreditation process.

\section{Research}

In 1999 the National Board of Examiners requested that all residents submit research reports with their application for the national examination.

\section{Examinations}

At the end of each year (in some institutes twice a year, midyear as well as end of year), each institute sets examinations. There are three sections: a written paper, a case interview and an oral examination. The written paper consists of three parts: 150 multiple-choice questions, sat in 3.5 hours; six modified essay questions (MEQs), sat in 3 hours; and six short essays, sat in 3 hours (five of these relate to psychiatry and one to neurology). The pass mark is $50 \%$.

For the case examination, trainees have to interview two psychiatric patients and evaluate one neurological case. They have 30 minutes to interview each patient and 45 minutes to summarise and answer questions. The pass mark is $60 \%$ for each case; marks are awarded by two independent examiners.

For their oral examination, trainees are assessed in 1 hour by three examiners in the following areas: knowledge, attitude towards the profession, cultural considerations, ethics, judgement and emergency decision-making skills. The examiners grade each area $A, B, C$ or $F$. Examinees will pass if they do not receive any Fs.

If trainees fail a case examination only, they will have a chance to resit within the following 6 months, but if they fail in written and case examinations they will have to resit the next year. After the examination, trainees are asked to provide feedback on the examination process to the National Board of Examiners.

Trainees who pass the National Board examination are qualified to apply to be Fellows of the Royal College of Psychiatrists of Thailand (RCPsychT). When their application has been approved by the executive committee of the College, they can use the letters FRCPsychT after their family names. As of 8 February 2007 there were only 407 Fellows.

\section{Conclusion}

Psychiatric residency training in Thailand is at present offered for only general and child and adolescent psychiatry. Training in other sub-specialties, such as geriatric psychiatry or forensic psychiatry, is not yet available. The number of doctors who apply for training in psychiatry is increasing, which means a bright future for teaching and training in Thailand can be expected.

\section{Further reading}

Udomratn, P. (2003) Psychiatric education in Thailand. ASEAN Journal of Psychiatry, 6, 102-106.

\section{Self-harm by poisoning in Mauritius}

\section{Mridula S. Naga, MBBS MRCPsych DPM(Lond)}

Senior Psychiatrist, Victoria Hospital, Mauritius, email drmridunaga@hotmail.com

\begin{abstract}
uicide rates and rates of self-harm are high in Mauritius.
This report concerns a comprehensive analysis of the incidence of self-poisoning on the island. The incidence of self-poisoning could be minimised if all the causative factors contributing to the practice were identified. Since this form of self-harm is influenced by demographic patterns, the social and economic environment, legal provisions and the healthcare system, a study specific to Mauritius will be of great relevance.

Self-harm is defined as a non-fatal act in which an individual deliberately caused self-injury or ingested a substance in excess of any prescribed or generally recognised dosage (Kreitman, 1977). The term self-poisoning is used when the
\end{abstract}

self-harm results from drug overdose or ingestion of other noxious agents and where there is no intention to die.

\section{Background}

The Republic of Mauritius is a group of islands in the southwest of the Indian Ocean, east of Madagascar, with a population of about 1.2 million. The population is multiracial and multi-ethnic, with origins from the continents of Asia, Africa and Europe: $68 \%$ of the population are IndoMauritians, 27\% are Creoles, 3\% are Sino-Mauritians and 2\% are Franco-Mauritians. Around $24 \%$ of the population are 